\title{
Clinical Experience of the Phenol Block to the Cerebral Palsied Children-60 Cases
}

\author{
by \\ Sueo Eguchi, Kenji Takada and Hiroshi Mizunaga \\ from
}

Kojikaen, Kochi Prefectural Hospital for Crippled Children, Kochi, Japan

60 casee of CP (spastic hemiplegia 3, spastic paraplegia 24, athetoid 7 , mixed 3) were given the phenol block with $5 \%$ phenol solution to facilitate the training and nursing care. Motor branches of hypertonic muscles, which disturb the ambulation, the ADL, and the nursing care of CP, were searched by teflon coated needle connected with the portable type electrostimulator. At most 4 times of the block had done to one muscle group, when the recurrence had occured after phenol block.

Spastic pes equinus were treated by motor point blocks (19 times), or tibial nerve blocks (83 times) of the calf muscles. All of the motor point block had recurred within 3 months. However, the tibial nerve block could have long term of effectivenss. More than 6 months of the effective duration has been gotten in 10 time trials of tibial nerve blocks.

The obturator nerve blocks ( 42 times) were done to decrease the adductor spasticity, which distorted the gait of $\mathrm{CP}$, and also disturbed the nursing care of severely crippled CP children. 28 times of the trial of obturator nerve blocks could have the long term of effectiveness. 19 times of them has been effective more than 6 months after the blocks.

4 cases of tension athetosis were treated by the block on thoracodorsal nerve, motor points of triceps brachii, and sciatic nerve to decrease the hypertonic state of the muscles. 1 case of them had the long term of effectiveness, and other 3 cases had the very short term of it.

Using the thin teflon coated needle to block the nerve trunk, for instance sciatic nerve, the target muscle would be blocked selectively. This comes from author's experience. Phenol block also had done to avoid second operation of Achilles tendon lengthening to correct pes equinus, and adductor tenotomy of the hip.

16 limbs got the phenol block of calf muscles to correct the recurred pes equinus after Achilles tendon lengthening. Three limbs also got the obturator nerve blocks to correct the recurred adductor spasticity following adductor tenotomy. 


\section{脳性麻痺に対するフェノールブロックの成績 （電気剌激装置とテフロン針使用） \\ —60 経験例を中心にして——}

江口寿栄夫* 高田賢治水永弘司

\section{I. 緒 言}

痤性麻盘による歩行, 車椅子, 日常生活動作 (ADL) などの障害を，テフロン加工の絶縁針と 電気刺激により, 経皮的に, かつ選択的に spasticityをもつ筋肉の運動神経枝を探し出し, これ をフェノール液（われわれは $5 \%$ の濃度のものを 使用）でブロックして, spasticity を減弱または消 失させて，訓練効果をあげることができる，本誌 第 7 巻第 2 号に, 装置と脊髄損傷患者を中心にし た臨床経験について発表したが，ここでは，肢体 不自由児施設における脳性麻㾝についての経験を 述べる.

\section{II. 対 象}

昭和 45 年 6 月より 47 年 4 月までの 1 年 11 力 月の間に, 脑性麻㾇児の 60 人についての もので あるが, そのらち分けは, 高知県立子鹿園（肢体 不自由児施設) 児 52 人と, 国立高知療養所第 1 つ くし棟(重症心身障害児施設) 児 8 人で, 前者の 52 人のらち, 単独入園児 44 人, 母子入園児 (年齢が 5 歳以下） 5 人, 外来通園児 3 人であった. これ 5 60 人の対象児の年齢では, 6 歳以下 10 人, 6 歳以上 50 人であった。 また, 脳性麻瘏の 型によ る 60 人のらち分けは, 病直性片麻瘏 3 , 対麻疩 24 , 四肢麻痷 24, アテトーゼ 7 , 混合型 3 人であ った。

対象児 60 人の歩行能力については, 表 1 のと おりで, 独歩しているもの 30 人と松葉杖歩行を

* 高知県立子鹿園
表 1 フェノールブロックの対象贤の歩行能力

\begin{tabular}{ll}
\hline 独步 & 30 人 \\
松葉杖または歩行器による歩行 & 19 \\
歩行不能 & 11 \\
\hline
\end{tabular}

（注）歩行不能11人では脛骨神経ブロック,下腿三 頭能運動点ブロックはなく, 閉鎖神経, 胸背神経ま たは坐骨神経ブロックであった。

表 2 フェノールブロックの部位別回数

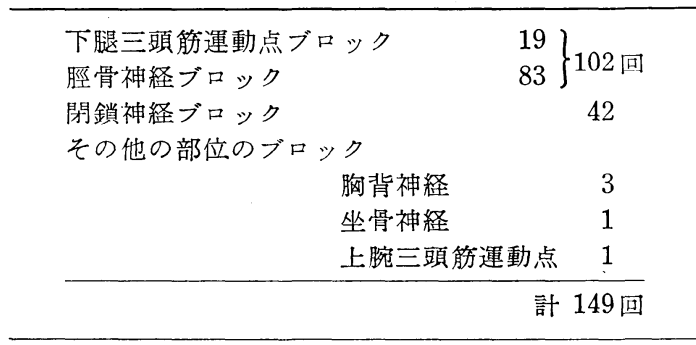

する 19 人は，いずれも子鹿園児で，尖足や鋏み 足跛行をしていて, ブロックにより, 歩容の改 善, 歩行の安定化を目的として行なわれた。一 方, 歩行不能の 11 人は, 病直性四肢麻瘏, 緊張 アテトーゼにより ADL も独立していない者で, 子鹿園の重度脳性麻瘦児 3 人之, 重症心身障害児 施設の 8 人 (いずれも脳性麻瘏による運動機能障 害が強い) で, 訓練効果を助ける目的のブロック と, 看護の介助を容易にするためにブロックをし たものとがあった。

表 2 は, ブロックの部位と, ブロックの回数を 示すが，下腿三頭筋の㽷直性すなわち尖足に対す るものが 102 回でもっとも多く, ついで閉鎖神経 に対するものが 42 回であった。このなかには, 
表 3 フェノールブロックの持続効果. 脛骨神経お よび下腿三頭筋運動点ブロック（73 肢，102 回）

\begin{tabular}{|c|c|c|c|}
\hline \multirow{2}{*}{ 持 続 期 間 } & ブロック回数 & ブロック回数 & \multirow[b]{2}{*}{ 計 } \\
\hline & 再 発 & 持続 $\left(\begin{array}{c}\text { 昭和 } 49 \text { 年 } \\
5 \text { 月現在 }\end{array}\right)$ & \\
\hline $0 \sim 1$ 週 & 3 (1) 回 & & 3 回 \\
\hline 1 週〜 1 力月 & $16(12)$ & 5 回 & 21 \\
\hline $1 \sim 2$ 力月 & $22(4)$ & 22 & 44 \\
\hline $2 \sim 3$ 力月 & $16(2)$ & 5 & 21 \\
\hline $3 \sim 6$ 力月 & 3 & & 3 \\
\hline 6 力月 1 年 & & 6 & 6 \\
\hline $1 \sim 1$ 年 6 力月 & & 2 & 2 \\
\hline 1 年 6 力月以上 & & 2 & 2 \\
\hline 計 & $60(19)$ 回 & 42 回 & 102回 \\
\hline
\end{tabular}

（注）再発の（）内は，運動ブロックでいずれも 再発

重度脳性麻疩览の用便介助の目的で閉鎖神経ブロ ックを行なった者も含まれている。その他とし て, 胸背神経ブロックの 3 回と, 上腕三頭筋運動 点ブロック 1 回は, 緊張アテトーゼで上肢の訓練 を助!るために行なったものであり，坐骨神経ブ ロックの 1 回は，患児の筋緊張による苦痛と，介 助を助けるために行なったものである。合計 149 回のブロックをしているが，電気刺激を行なうの で，いずれも前投薬を行ない，症例に応じて全身 麻酔, 迷朦麻酔, 局所麻酔, 無麻酔のもとでブロ ックを施行した。

\section{III. 成 績}

フェノールブロックの効果は, 臨床的には長期 間続く一種の麻酔作用と考兄てょく，したがっ て，その効果の持続が一番問題になる。ブロック の確実性については, 絶縁針と電気刺激により, 明確に該当筋肉の神経枝を探すことができるので 問題はない。ブロック後は, その拮抗笳の強化, 受動的な該当筋の伸展, 装具による矯正位保持に より，ブロックの効果を維持することを原則とし ているが，閉鎖神経ブロック，上肢のブロックで は，装具はまったく使用しなかった。

表 3 は，下退三頭筋の痤性尖足に対する脛骨神 経ブロックと，下腿三頭筋運動点ブロックの効果 の持続の程度を示したものである。73肢に 合計 102 回のブロックを行なったが，再発は半数以上
表 4 フェノールブロックの持続効果. 閉鎖神経ブ ロック（39 肢，42 回）

\begin{tabular}{|c|c|c|c|}
\hline \multirow{2}{*}{ 持続期間 } & ブロック回数 & \multirow{2}{*}{$\frac{\text { ブロック回数 }}{\text { 持続 }\left(\begin{array}{c}\text { 昭和 } 47 \text { 年 } \\
5 \text { 月現在 }\end{array}\right)}$} & \multirow{2}{*}{ 計 } \\
\hline & 再 発 & & \\
\hline $0 \sim 1$ 週 & 1回 & & 1回 \\
\hline 1 週〜 1 力月 & 2 & 3回 & 5 \\
\hline $1 \sim 2$ 力月 & 2 & & 2 \\
\hline $2 \sim 3$ 力月 & 4 & 2 & 6 \\
\hline $3 \sim 6$ カ月 & 5 & 4 & 9 \\
\hline $6 \sim 1$ 年 & & 10 & 10 \\
\hline $1 \sim 1$ 年 6 力月 & & 8 & 8 \\
\hline 1 年 6 力月以上 & & 1 & 1 \\
\hline 計 & 14回 & 28回 & 42 回 \\
\hline
\end{tabular}

表 5 フェノールブロックの持続効果

胸背神経ブロック 3 回

汪射回数 3 のうち再発 2 回 ( $1 \sim 2$ 週), 持続 1 回（6力月上上)

上腕三頭笳運動点ブロック 1 回 注射回数 1 でほとんど無効

坐骨神経ブロック 1 回 注射回数 1 で再発（効果は 1 週間のみ）

の 60 回にみられ，とくに運動点ブロックは（ ） で示してあるが，最高 3 カ月までの持続効果で, いずれも再発した．昭和 47 年 5 月現在の持続効 果であるが，半年以上 1 年までの持続は 6 回， 1 年以上は計 4 回にみられ, 脛骨神経ブロックの方 が，持続効果を得るには優れていた。

病性尖足に対してのブロック後では, 矯正位保 持用の装置を着ける方が，明らかに効果の持続が 期待できるが，これに関しては，子鹿園の理学療 法士尾崎が，第 16 回 全国肢体 不自由児施設療育 研究大会で, 「脳性麻瘏の痤性跛行に対するフェ ノールブロックの経験」の演題で発表済みである (雑誌「療育」に投稿中).

表 4 は，内転筋群の緊張が強いために，鋏及足 跛行を示すもの，重度脳性麻疩児で用便などの ADL，介助の困難なものを対象に，閉鎖神経ブロ ックを行なった結果を示す． 39 肢に 42 回のブロ ック回数であるが, その効果の持続は, 脛骨神経 ブロック，下腿三頭筋運動点ブロックよりは，も つと期待できる。すなわち，再発は14 回にみら れたが，効果の持続は，昭和 47 年 5 月現在で 28 
表 6 フェノールブロックと手術. 下腿三頭筋運動 点ブロックまたは脛骨神経ブロックとアキレス健延 長術

\begin{tabular}{|c|c|c|c|c|}
\hline $\begin{array}{l}\text { ブロックと手術 } \\
\text { ブロック回数 }\end{array}$ & 1 回 & 2 回 & 3 回 & 4 回 \\
\hline $\begin{array}{l}\text { ブの } \\
\text { ロみ } \\
\text { ッ } \\
\text { ク }\end{array}\left\{\begin{array}{l}\text { 効果持続 } \\
\text { 過剩効果 } \\
\text { 再発または無効 }\end{array}\right.$ & $\begin{array}{r}17 \\
2 \\
9\end{array}$ & 6 & 1 & 1 \\
\hline $\begin{array}{l}\text { ブロック後アキレス腱延 } \\
\text { 長術 }\end{array}$ & 17 & & & \\
\hline $\begin{array}{l}\text { アキレス腱延長術後ブロ } \\
\text { ック }\end{array}$ & 7 & 7 & 2 & \\
\hline 計 73 肢 & 52肢 & 15肢 & 4 肢 & 2 肢 \\
\hline
\end{tabular}

回あり，2 倍で，かつ，6力月以上の効果の持続 が計 19 回であった。ここで, 重度脳性麻瘏児で 用便介助を容易にするためにのみブロックを行な ったものも，1 日に数回以上の開排位を，おむむ 交換のためにとらすので, それが内転筋群の伸展 になっていた。

表 5 は, 胸背神経ブロック, 上腕三頭筋運動点 ブロック，坐骨神経ブロックの回数を示すが，い ずれも対象は緊張アテトーゼであり, 胸背神経ブ ロックの 1 回にのみ，その効果の持続をみてい る. この例は, 左肩関節が伸展, 内転, 内施位を とって, 屈曲が自動的にはまったく不能で, 他動 的には軽度可能であったのが, 胸背神経ブロック 後は, 自動的な屈曲が軽度に可能となり, 上肢訓 練に効果的で, 現在 6 力月以上の持続効果を得て いる. 同様のケースがもら 1 人あって，2 回胸背 神経ブロックを行なったが, 2 回とも，1〜2週 後に再発をみた. 上腕三頭筋運動点ブロックは 1 例にのみ行なったが，ほとんど無効であった．坐 骨神経ブロックは，1例の年長の緊張アテトーゼ の要全介助の児で, 患児の緊張による苦痛と, 介 助を容易にするために行なってみたが，約 1 週間 で完全に再発していた。なお，このケースでは知 覚異常はほとんどなかったが，注射部位の圧痛を 2 日間訴えた。

\section{IV. フェノールブロックと手術}

フェノールブロックのみを単独で行ない, 訓 練, 装具着用により十分な効果が得られるのが理 想であるが，すでに拘縮が起こっていて，ブロッ
表 7 フェノールブロックと手術。閉鎖神経ブロッ クと股内転筋切腱術

\begin{tabular}{|c|c|c|}
\hline ブロックと手術 ブロック回数 & 1 回 & 2 肢 \\
\hline $\begin{array}{l}\text { ブク } \\
\text { 口の }\{\text { 効果持続 }\end{array}$ & 26 & \\
\hline ッみ |再発または無効 & 6 & 3 \\
\hline ブロック後内転筋切腱術 & 1 & \\
\hline 内転笳切腱術後ブロック & 3 & \\
\hline 計 39 肢 & 36肢 & 3 回 \\
\hline
\end{tabular}

クの効果の期待ができないもの, ブロックをして もたびたび再発するもの, また, 腱延長や切腱術 後に再発してきているものに対して,フェノール ブロックを行ならことにも効果が期待できる.と くに，同じ手術を再度行ならことは，患児はもち ろん, その両親, 術者たる整形外科医にとって も, やはり苦痛である。

表 6 は，IIIで述べた脛骨神経ブロックおよび下 腿三頭筇運動点ブロックを行なった 73 肢につい て, ブロックのみのもの, アキレス腱延長術との 組み合わせでブロックを行なったものを表にした ものである.

表によると，ブロック後にアキレス腱延長術を 行なったものは 17 肢あり，いずれもブロック後 の再発例であった.アキレス腱延長後, 痠性尖足 の再発があってブロックを行なったものは計 16 肢であった。この 16 肢のらち， 1 回のブロック 7 肢, 2 回のブロック 7 肢, 3 回のブロック 2 肢 であるが，いずれも，昭和 47 年 5 月現在，効果 の持続がみられている，一方，ブロックのみで 効果の 持続がみられているものは, 計 25 肢で, そのらち, 1 回のブロックで効果の持続を示して いるものは 17 肢であった。 過剩効果とあるのは 2 肢で, 両側の脛骨神経ブロックを行なってか ら, 尖足が逆に, 踵足が強くなりすぎ, 歩行能力 が著しく低下したものであるが，両側の下腿三頭 筋の病性が約 2 力月後に少し戻ってきて, 歩行能 力が戻ってきた 1 例であった. ブロックのみで再 発または無効（ブロックの効果の持続が 1 週間前 後で短く, 臨床的に効果がまったく不十分）であ ったものは 13 肢であり，再度のブロックか，ア キレス腱延長術などの下腿三頭筋に対する観血的 
手術が必要である.

表 7 は，閉鎖神経 ブロックを行なった 39 肢の 手術に対するらち分けを示す。これによるとブロ ック後再発して股内転筋切腱術をしたものは 1 例 のみであった。 また切腱術後, 再発の傾向があっ たのでブロックをしたものが 3 肢にあったが，い ずれも昭和 47 年 5 月現在, 効果の持続が みられ ている．以上の手術に関しては，手術手技の関連 が多少あるであろう。しかし, 閉鎖神経ブロック の効果は非常によく，1回のブロックのみで十分 な効果が持続しているものは表のとおりで 26 肢 であり，手術回数を減らすことができると判断さ れる．再発または無効は計 9 肢にみられたが， 1 回のブロックで再発したものは 6 肢, 2 回とも再 発したものは 3 肢であった。

なお，表 6,7 で無効とあるのは，ブロックの 効果の持続が 1 週間前後で短く, 臨床的に効果が まったく不十分であったものである.

\section{V. 考 按}

観血的に運動神経枝を探して,これに稀薄フェ ノール液を直接注射してブロックした。その効果 についての発表は, 日本では, 昭和 44 年ごろま であったが，テフロン加工の絶縁針を使用して， 経皮的にかつ選択的に, spasticity の強い筋肉の 運動神経枝を見出し，これにフェノール液を注射 してブロックすることが知られて以来, 最近では リハビリテーションの分野で，しだいに実施さ れ，訓練効果をあげてきている。

われわれは, 持ち運びの便利な電気刺激装置を 作成し，普通の注射針の針の部分のみをテフロン 加工した絶縁針を使用しているが, 要するに, 経 皮的に刺激導子で病性の強い筋肉の運動神経枝を 探し出して, ブロックすればよいわけである。 ま たわれわれは5\%フェノール液を使用している が,これは, 2〜3\%フェノール液よりも, 効果の 持続期待できるからで, 以前に $2 \sim 3 \%$ フェー ル液を使用したころの経験と, 友人である Bellevue 病院の Dr. Dhir の指摘による. むちろん, $\gamma$ 線維の選択的なブロックとはいえなく， $\alpha$ 線維 もある程度ブロックされるのはやむをえないが， $2 \sim 3 \%$ フェノール液が, 質的に, 選択的に $\gamma$ 線
維の久をブロックするといらことは否定されてい るし, 臨床上, $\alpha$ 線維をブロックしたとしても， 過剰でなければ——実際上はそう多くない— spasticity に対するブロックの効果としては十分 得られるとみてよい.

混合神経である脛骨神経ブロックの場合, 足底 部の知覚異常ないし知覚鈍麻を認めたものが 1 例 あったが，約 1 カ月で消失した．閉鎖神経扣よび その他の神経ブロックでは, 知覚障害を訴えたも のはなかった。経験的に細い絶縁針を使えば, 神 経幹を電気刺激して, 個々の筋肉の攣縮をみるこ とから，混合神経でも細い針を使えば，知覚障害 を避けられることが多いと思う。注射部位の疼痛 も，坐骨神経ブロックした 1 例に中等度の疼痛を 訴えたが，ほとんどの症例で疼痛の訴えはあまり なく, かつ, 翌日からの訓練に十分耐えられるも のであり，しかも短期日の間に消失している.

フェノールによる副作用は量的な考慮を払えば よく,われわれの経験では, 体重 $\mathrm{kg}$ あたり 0.1 cc を限度量として考えている。 しかし，血管内 への注入は，絶対避けなければならないことはい らまでもない。

経皮的に入れた絶縁針の先が, 運動神経(枝)に 刺入した場合にフェノール液を注入したら持続効 果が長いが，運動神経(枝)の縁に針先があたって いても同様の筋肉の攣縮が起こるので, このょう な場合に注入すると, ブロックの効果は短いと考 えられる. 運動点ブロックが, 脛骨神経ブロック よりも再発しやすいのは, 運動点における運動線 維が細く, かつ分散しているので，上述の後者の ような場合が多いのではないかと解釈している. 手技的には，確実かつ強い筋の攣縮のある場所を 深し出して，ここをブロックすることを目標とす るとよいと判断している.

下腿三頭筋のブロックでは, spasticity の減弱 ないし消失とともに push off が弱くなる面もあ るが，しだいに回復してきて，かつ踵の接地が得 られ, 歩容が改善し, また安定化する。しかし, 歩行のスピードは, 下腿三頭筋, 腱の延長術後と 同様はじめのうちは push off の低下で, かえっ て遅くなることが分っている. 閉鎖神経ブロック では, ブロックの持続効果は一層期待できるが, 
手技としては閉鎖孔より出てくる閉鎖神経を挆す ため，長針を使わねばならず，また少し時間がか かることが多い，しかし，電気刺激をしながら探 せるので確実性がある．脛骨神経ブロックの時 は, 膝窩部で神経線維に直角に絶縁針を刺入する ため，その断面におけるブロックといらことにな るが，閉鎖神経では神経に沿って針を刺入して探 してブロックを試み，かつ何回か確かめるので, 神経線維の多くの断面でブロックすることとな り，したがってその効果の持続も長く続くのでは ないかと考えている．閉鎖神経ブロックでは，鋏 久足，内転跛行の改善の久ならず，用便の始末が できやすくなるといった ADL 上の向上や，看護 介助の助けにもつながる.

緊張アテトーゼの訓練は，なかなか効果をあげ にくく, かつ, 手術的な侵襲も不確実である.わ れわれの少ない経験ではあるが，神経ブロックに より，アテトーゼシフトといったものの経験はま だないが，これから症例を増すつもりである。ま た神経ブロックにより, 手術の効果をある程度予 測できるので, 緊張アテトーゼに対する手術（神 経抢よび筋腱切離術）も，少し開けるのではな いかと，ほのかな期待も持っている。

重症心身障害児施設に扮ける重度の脳性麻疩 で，筋緊張は看護を困難にすることが多いが，閉 鎖神経ブロック後, おむつの介助が以前より容易 になり，患児の苦痛も軽減するのをみて，機能向 上でなく，看護面の容易さからみて，手術に同意 する両親もでてきていることも付記したい.

本論文の要旨は, 第 9 回日本リハビリテーション医学 会総会において発表した。賛助して下さつた児玉俊夫教
授, $\mathrm{OG}$ 技研 $\mathrm{KK}$ に感謝します

\section{文 献}

1) Khalili, A., A., et al. : Management of Spasticity by Selective Peripheral Nerve Block with Dilute Phenol Solutions in Clinical Rehabilitation. Arch. Phys. Med., 45 : 513, 1964.

2) Khalili, A.A. \& Benton, J.G. : A Physiologic Approach to the Evaluation and the Management of Spasticity with Procaine and Phenol Nerve Block, Including a Review of the Physiology of the Stretch Reflex. Clin. Orthop., $47: 97,1966$.

3) Katz, J., et al. : Peripheral Nerve Injections with Phenol in the Management of Spastic Patients. Arch. Phys. Med., 48 : 97, 1967.

4) Knott, L. W., Katz, J. and Rubinstein, L. J. : Separate and Combined Effects of Phenol, Hyaluronidase and Dimethyl Sulfoxide on the Sciatic Nerve of the Rat. Arch. Phys. Med., 49 : 100, 1968.

5) Fusfeld, R. D. : Electromyographic Findings. After Phenol Block. Arch. Phys. Med., 49 : 217, 1968.

6) Glass, A., et al. : Electromyographic and Evoked Potential Responses After Phenol Blocks. of Peripheral Nerves. Arch. Phys. Med., 49 : 455, 1968.

7) Lusskin, R., et al. : Rehabilitation Surgery in Adult Spastic Hemiplegia. Clin. Orthop., 132, 1969.

8) B. J. De Lateur, M. D. : A New Technique of Intramuscular Phenol Neurolysis. Arch. Phys. Med., 53 : 179, 1972.

9）江口:臨整外, $5: 364,1970$.

10) 江ロ：リハビリテーション医学, $7: 119,1970$.

11) 尾上, 江口, 堅山：中部整災誌, $14: 543$, 昭 46.

12）村上・他：日整会誌， $43: 911 ， 1969$.

13）坂田・他：中部整災誌，12，1086，昭 44 . 